\title{
National Insecurity and the Challenges of Food Security in Nigeria
}

\author{
Agaptus Nwozor, Ph.D ${ }^{1^{*}}$ \\ John Shola Olanrewaju, Ph. ${ }^{1}$ \\ Modupe B. Ake, Ph.D ${ }^{1}$ \\ ${ }^{1}$ Department of Political Science and International Relations \\ Landmark University, Omu-Aran, Kwara State, Nigeria \\ ${ }^{*}$ Corresponding Author
}

Doi: 10.36941/ajis-2019-0032

\begin{abstract}
Nigeria has been overly dependent on oil for its foreign exchange earnings and government revenue since the oil boom of the 1970s. Prior to this period, the country was reasonably self-sufficient in food production and carved a respectable niche for itself as a major exporter of several cash crops. However, as agriculture lost its primacy to oil, it went into steady decline due to neglect by successive governments. The neglect led to mass abandonment of farms resulting in extreme peasantization of the sector. A related negative fallout was Nigeria's transition from food self-sufficiency to food-dependency and attendant massive importation to bridge food gaps. However, efforts are being made by the government to reposition the agricultural sector to boost its productive capacity and make it competitive. The major task of this study is to evaluate Nigeria's quest to achieve food security against the backdrop of national insecurity. Considering the categorization of Nigeria as food insecure, the study examines the interconnection between national insecurity and food production as a prelude to the actualization of food security. The study relies on primary and secondary data to evaluate the feasibility of food security in the face of sustained insecurity across the country. The study finds that the achievement of food security would be impossible if the insecurity that pervades and envelopes farming communities is not resolved.
\end{abstract}

Keywords: food security, national insecurity, agricultural sector, food insecure, Nigeria

\section{Introduction}

The key thrust of Nigeria's agricultural renaissance is to diversify its economy by making agriculture the hub of economic growth while also achieving a hunger-free country. A hunger-free country is one that is food secure. Food security has become a national priority for the country considering that a vast majority of its 198.1 million population is food insecure (FMARD, 2016). Food and nutrition insecurity is prevalent in Nigeria despite its favorable agro-ecological endowments. It has a total landmass of 92.4 million hectares, out of which only about 32 million hectares or 34.63 percent are under cultivation. Nigeria, therefore, lacks both the capacity and capability to cater for the food and nutrition requirements of its teeming population. As such, food insecurity and the prevalence of under-nutrition in Nigeria are among the worst globally (Fadare et al, 2019).

The picture of Nigeria's food and nutrition insecurity has been on worsening trend. According to FAO et al (2019), between 2004 and 2006, the total number of undernourished Nigerians was 9.1 million. This number increased to 25.6 million people or 281.32 percent in the period between 2016 and 2018. As Nigeria's population, which has growth rate of 3.1 percent continues to expand, the food and nutrition requirements of the country would also increase with the likelihood that food 
and nutrition insecurity might assume alarming dimensions.

Although Nigeria is yet to devote 10 percent of its annual national budget to agriculture to be on track to achieving 6 percent growth in productivity as projected in the Comprehensive Africa Agricultural Development Program (CAADP) and the ECOWAS Agricultural Policy (ECOWAP) documents, it initiated major agricultural policies from 2010 and has been pursuing them (FMARD, 2016). Although modest progress has been made in the production of cassava and rice, there are still enormous gaps between domestic production and demand for many staple crops. Thus, Nigeria expends huge amount of its scarce resources on food importation. Nigeria's Central Bank sources indicated that the country's monthly import bill in 2015 was US\$665.4 million. However, new data from the same source showed that the figure had drastically fallen to US $\$ 160.4$ million monthly by October 2018 (Popoola, 2018). Notwithstanding these snippets of success, the overall picture is that Nigeria is grossly food and nutrition insecure with the lurking danger that it could slip into acute food insecurity without warning due to the erosion of agricultural productivity by national insecurity.

Undoubtedly, there are immense potentials in Nigeria's agricultural sector, which if properly managed would unleash income growth for farmers, food and nutritional security, and employment opportunities as well as elevate the country to the ranks of leading players in global food markets. (FMARD, 2011). However, there are various barriers to repositioning Nigeria's agricultural sector. These include among others, uncompetitive environment for agribusiness, underinvestment, corruption, lack of access to credits as well as quality agricultural inputs, weak implementation of policies, poor market access and national insecurity (Downie, 2017). The major threat to the agricultural sector is insecurity from both the Boko Haram and Fulani herdsmen. In the northeast of Nigeria, the sustained terrorist activities of the Boko Haram have had negative impact on agricultural activities. Not only are farming activities incapable of being carried out under an insecure environment, domestic agricultural production is stifled, farming communities are displaced and access to regional market is blocked (Eigege \& Cooke, 2016). In addition to the Boko Haram group, the Fulani herdsmen have become a major threat to farming communities due to incessant attacks on these communities with attendant fatalities.

In evaluating Nigeria's quest to achieve food security, this study underscores the impediment that insecurity poses to the realization of food security. It highlights that the destructive impacts of insecurity are antithetical to farming activities and, as such, would lead to food shortages and worsen the already bad food insecurity profile of Nigeria. The study employed primary and secondary data to address its major objective of examining the interconnection between national insecurity and the feasibility of achieving food security in Nigeria. It generated its primary data from interviews organized for eight key informants drawn from diverse backgrounds. These informants were chosen through the instrumentality of convenience sampling technique of nonprobability sampling method. The secondary data were obtained from archival materials including official documents from the Nigerian government and international non-governmental and intergovernmental organizations. The study found that national insecurity crowds out agricultural productivity. In other words, the disruptions from the activities of the Boko Haram group and Fulani herdsmen undermine the capacity of farming communities to produce optimally thereby creating food shortages that ultimately deepen the food insecurity profile of the country.

\section{The Linkages: Exploring the Nexus between Food Security and National Security}

For the past twenty years, issues relating to food security have constituted a major focus of the policy thrust of the international community. As a matter of fact, it formed part of the major goals, which the world leaders initially agreed to devote resources to actualizing by 2015 but now by 2030 . Thus, from the millennium development goals (MDGs) which the world leaders launched in 2000 to its successor, the sustainable development goals (SDGs), the global focus has crystalized from the desire to eradicate extreme poverty and hunger to the determination to ensure "no poverty" and "zero hunger" by 2030. However, the achievement of these two noble goals among the 17 goals that constitute the SDGs may be difficult to realize in conflict-ridden environments.

The concept of national security has metamorphosed over time. Thus, from state-centric view of the realist school, which is centered on the twin preoccupations of regime survival and the 
preservation of the territorial integrity of the state system, national security has expanded and become multilayered as it draws deeper and broader insights from other schools of thoughts and disciplines. Therefore, national security is no longer to be understood from the narrow, restrictive, militaristic and strategic perspective that focuses on the absence of threats to governmental authority and the presence of domestic capacity to contain activities from centrifugal forces whether in terms of internal subversive activities or as external attempts to sabotage and attack the state (Nwozor, 2018).

The refurbishment of the concept of national security has produced a paradigmatic shift in its contemporary definitional criteria as it is now conferred with added quality and dynamism. Nwozor (2013) has pointed out that national security now transcends the traditional frontiers of statecentrism and incorporates man and the environment within the milieu of sustainability. Thus, within the precinct of this conceptualization, national security may be viewed as a multidimensional phenomenon whose leitmotif centers on safeguarding national values, which in turn encompasses all the actions taken by the state in furtherance of its diverse policies concerning its overall security whether symbolic, physical or psychological. These national values may span the environment, economic security or security of the economy, sustainability of the planetary ecosystem, and the reconciliation of the competing interests of the various classes in the state (Nnoli, 2006; Nwozor, 2013).

National security is intrinsically linked to human security. Indeed, human security is at the epicenter of national security. Human security prioritizes the security of the individual over that of the state since there can be no state without its citizens. Louw and Lubbe (2017, p.17) have noted that human security "primarily focuses on protecting the integral worth of people against insecurities" by dealing with "the circumstances that threaten the well-being and survival of the people". Thus, human security emphasizes the "establishment of food and water security, economic and political security for the general population as critical mechanisms to achieve a more stable level of state security" (Lanicci et al, 2017, p.17).

Since almost every state constitutionally pledges to pursue the welfare of its citizens, their national security framework must necessarily incorporate policy thrusts that focus on, and reify issues that are promotive of human security. Thus, the major objective of national security is to achieve complete security for both the state and its citizens by engendering an environment of peace. Therefore, it is a peaceful environment that catalyzes the realization of people's wellbeing. A peaceful environment must reassure the citizens of their safety from every form of symbolic, physical and psychological threats. The reassurance must be anchored on the demonstrated capacity of the state to guarantee an environment where citizens would be safe to pursue their livelihood activities.

One of the major pedestals upon which human security stands is the guarantee that everyone will have access to the necessities of life, of which food is an integral component. Thus, when there is no food or food shortage in a polity, it could lead to all sorts of insecurity (Notaras, 2011; Berazneva \& Lee, 2013). The centrality of food in the framework of development underscores the global quest to ensure its availability. The achievement of food security has, therefore, become the major goals of not just nation-states but also the global community.

Issues relating to food security initially only focused on food supply problems with particular reference to the availability of adequate supplies of basic foodstuffs as well as price stability at the national and international levels with considerations also given to adequate nutrition and well-being (FAO, 2003). Since 1974, the concept of food security has undergone series of refinement starting from when it was simply conceptualized in terms of availability and adequacy of food supplies to sustain a steady expansion of consumption to when issues of securing access by vulnerable people and having enough food to lead an active, healthy life became its emphasis. Now, the issue of nutrition has been incorporated as an integral component of food security and it is referred to as food and nutrition security. Thus, food and nutrition security is presumed to exist "when all people at all times have physical, social and economic access to food, which is safe and consumed in sufficient quantity and quality to meet their dietary needs and food preferences, and is supported by an environment of adequate sanitation, health services and care, allowing for a healthy and active life" (FAO, 2012, p. 8). 
Several factors contribute to food security in national settings. The key factors include favorable agro-ecological conditions, access to land, good agricultural policies that ensure sustained public and private investment in the sector, availability of farm inputs in terms of quality and quantity and peaceful atmosphere. If these factors are lacking in states, the likelihood of their meeting their food expectations may be a mirage. And if there is a shortfall in the availability of food, such that a cross section of the population could face the likelihood of food crisis, national security could be compromised as it could spark social unrest.

Evidence abounds with regard to food crises leading to unrest and even revolutions, which undermine national security. Historical evidence exists that demonstrates a link between higher food prices and violent riots. This linkage was quite evident during the global food crisis of $2007 / 2008$ when the then record-high food prices prompted riots across several countries in various parts of the world irrespective of the type of government in operation (Notaras, 2011; Berazneva \& Lee, 2013; Navarro, 2017).

In Nigeria, food insecurity is worsened by national insecurity as a result of protracted armed conflicts involving sundry groups, especially the Boko Haram group and Fulani herders. The activities of these groups in terms of invasion and sacking of farming communities have resulted in many civilian fatalities, thus creating acute insecurity. The state of insecurity in many of these farming communities has made it practically difficult for farmers to continue to engage in agricultural production optimally, thus affecting productivity and causing market disruptions with attendant food price shocks (Fadare et al, 2019). Therefore, a peaceful environment is a sine qua non for productive agricultural engagement, which results in food security. Food insecurity, on the other hand, mounts pressure on national security and invariably exacerbates national insecurity. Thus, sustainable food security under peaceful environment is an indispensable requisite to ensuring national security.

\section{Reinventing Agriculture for National Development: Mapping Nigeria's Quest for Food Sufficiency}

Prior to the discovery of oil in commercial quantity in Nigeria's Niger Delta in 1956, agriculture occupied a central place in the Nigerian economy. There was a healthy economic competition among the then four regions of the country as each exploited its comparative advantage by focusing on the cultivation and production of specific set of cash crops. Thus, Nigeria was reasonably self-sufficient in food production and carved a respectable niche for itself as a major exporter of a bouquet of cash crops ranging from groundnuts, palm oil, cocoa, rubber to cotton, including hide and skin (Smith, 2018; Okotie, 2018).

The dominance of agriculture in the Nigerian economy then could be seen from its contributions. Not only was agriculture able to cater for the 95 percent of the food needs of Nigerians, it contributed 64.1 percent of the Gross Domestic Product (GDP) and employed over 70 percent of the Nigerian population (Paul, 2015). Additionally, at that point, export of agricultural produce accounted for 80 percent of the country's foreign exchange earnings and 50 percent of government revenue (Okotie, 2018). However, the oil boom of the 1970s changed everything as the country became overly dependent on oil for its foreign exchange earnings. Since the mid-1970s, oil began to account approximately 95 percent of the country's foreign exchange earnings (Ikpeze et al, 2004; Okotie, 2018).

The oil boom led to an unprecedented inflow of foreign exchange that the then Head of State, Yakubu Gowon, was delirious with wealth and boasted that Nigeria's problem was not money but how to spend it (Ikpeze et al, 2004). It was estimated that between 1973 and 1981, Nigeria earned over N60 billion (about US\$90 billion) from oil and adopted a spendthrift attitude (Ikpeze et al, 2004). A major casualty of the oil boom was the agricultural sector as it was neglected. With the neglect of the agricultural sector, it faded in appeal and most farmers abandoned their farms to participate in sharing from the windfall produced by the oil boom. According to Pinto (1987), the oil boom led to a severe disruption in the agricultural sector, which manifested in a large exodus of labor to the cities. The consequence of this shift was the peasantization of agriculture with attendant declining productivity. 
Additionally, lack of government interest also resulted in poor policy intervention, such that farmers relied on obsolete crop varieties and over-aged trees to keep afloat. In other words, Nigeria did not flow with the tide of global best practices in the agricultural sector. As Okotie (2018) has pointed out, not only did Nigeria cease to be a major exporter of those cash crops for which it was previously renowned, such as cocoa, groundnut, rubber, and palm products, agriculture in the country's export profile dropped from 80 percent in 1960 to less than 2 percent. This was so because of the declining productivity in these cash crops. For example, between 1970 and 1982, annual production of these major cash crops, namely, cocoa, rubber, cotton, and groundnuts fell by 43, 29, 65, and 64 percent, respectively (Pinto, 1987).

Another consequence of wholesale abandonment of agriculture was that the share of agricultural imports in Nigeria's total imports expanded from about 3 percent in the late 1960s to about 7 percent in the early 1980s. With this expansion, Nigeria began its journey as a net importer of food. In 2015, Nigeria's monthly food import bill was put at US\$665.4 million (Popoola, 2018). Despite the various national development plans that Nigeria implemented as well as some specialized agriculture-oriented policies, the agricultural sector has not recovered its past glory as its practice is still at the subsistence level without modern implements that could maximize productivity. It would appear that notwithstanding these various agricultural interventionist policies, Nigeria was only paying lip service to revamping the agricultural sector. This proposition derived its logic from the disconnect between these policy avowals and the current state of the agricultural sector.

Since the 1970s, successive governments have been emphasizing their desire to diversify the economy and reinstate the agricultural sector as a major driver of the Nigerian economy. However, nothing much has changed as the sector is still backward despite its potentials. Thus, from such agriculture-oriented policies as "Operation Feed the Nation" floated by the military regime of Olusegun Obasanjo in 1976, the "Green Revolution" flagged off by the administration of Shehu Shagari in 1982, the "National Economic Empowerment and Development Strategy" (NEEDS) rolled out by Olusegun Obasanjo in 2004, the "Agricultural Transformation Agenda" launched by the administration of Goodluck Jonathan in 2011 and the "Agriculture Promotion Policy" (APP) introduced by Muhammadu Buhari in 2016, no significant milestone has yet been recorded in the agricultural sector. Oil still dominates the Nigerian economy as the major foreign exchange earner for the country.

As part of the global effort to leverage on agriculture towards the actualization of SDGs 1 and 2 , the global community has been emphasizing on the indispensability of agriculture. The New Partnership for African Development (NEPAD) believes that the agricultural sector is the engine of economic growth in Africa. Thus, African leaders under the auspices of the African Union (AU) and NEPAD evolved a continental strategy in Maputo in 2003 called the Comprehensive Africa Agricultural Development Program (CAADP) to revitalize and leverage on the agricultural sector to drive development on the continent.

The CAADP is, therefore, a continental platform designed for collaboration among African countries to promote modern and sustainable agriculture that would enhance productivity and competitiveness, thereby guaranteeing food security and providing decent incomes to farmers and other agricultural workers. The key target of the CAADP is to achieve 6 percent growth in productivity with the expectation that African states would devote at least 10 percent of their annual national budgets to agriculture. According to NEPAD (2003), the CAADP is anchored on five mutually reinforcing pillars to rescue and reposition African agriculture. These pillars include: i) extending the area under sustainable land management and reliable water control systems; ii) improving rural infrastructure and trade-related capacities for improved market access; iii) increasing food supply and reducing hunger; iv) investment in agricultural research, including dissemination and adoption of technology; and v) pursuit of sustainable development of livestock, fisheries and forestry resources (NEPAD, 2003; Kolavalli, et al, 2010).

In line with the CAADP, the Economic Community of West African States (ECOWAS) developed its agricultural policy named ECOWAP in 2005. Thus, the ECOWAS Agricultural Policy (ECOWAP) is in tandem with CAADP and its thrust centers on the promotion of modern and sustainable agriculture in order to satisfy the food requirements of the population, contribute to 
socio-economic development, reduce poverty in the sub-region and deal with inequalities among countries. Nigeria has keyed into the ECOWAP/CAADP agenda to revamp its agricultural sector as part of the overall of objectives of diversifying its monocultural economy and achieving food security.

Nigeria's two most recent policy thrusts are the Agricultural Transformation Agenda (ATA) that was launched in 2011 and the Agriculture Promotion Policy (APP) (also referred to as the Green Alternative), which was flagged off in 2016. The many years of neglect of agriculture by successive governments created complex contradictions in that sector. The foremost of these contradictions are the twin-problems of inadequacy of food production resulting in the inability to meet domestic food requirements, and the poor quality of crops because of poor knowledge of modern agronomy practices (FMARD, 2016). Both of the aforementioned contradictions are manifestations of the backwardness of Nigeria's agricultural sector.

Thus, the most contemporary agricultural policies of Nigeria, that is, ATA and APP, recognized the deficits and the great potentials in agriculture in terms of boosting employment opportunities, ensuring food security, providing a better quality of life and alleviating poverty and, therefore, were tailored to reposition the agricultural sector. The ATA was a departure from the way that previous interventionist policy instruments were conceptualized and implemented in the bid to restructure the agricultural sector (FMARD, 2011). The point of departure was the conceptualization of agriculture as a business and not a development project where the government would sink in money without clear-cut deliverables and expectations. Thus, within the framework of ATA, the primary role of the government was to create an enabling environment for private-sector leadership in providing all necessary inputs and services (FMARD, 2011). The APP, is the successor policy to ATA. In addition to building on the successes of ATA, the core mission of APP is to create an agribusiness economy with focus on meeting domestic food security goals of the country and delivering sustained prosperity to workers and investors in the agricultural sector (FMARD, 2016). Thus, the policy thrusts of APP revolve around four key themes, namely, food security, import substitution, job creation, and economic diversification.

The crux of Nigeria's agricultural policy is to boost agricultural production such that the country would be food secure and cease to depend on food importation as prelude to achieving food security. Thus, the efforts of the government essentially consist of taking advantage of the country's natural endowments and favorable environment to boost food production and agro-allied industrial activities. Nigeria's natural endowments consist of a total landmass of 92.4 million hectares, of which about 79 million hectares are arable. Currently, only about 32 million hectares are under cultivation (FMARD, 2010). Agricultural activities are still stuck at the level of subsistence with majority of actors in the sector being smallholder farmers. Besides the peasant structure of the agricultural sector, it is still dominated by traditional agricultural methods with scant space for modern agronomy practices. Thus, several presidential initiatives, which were implemented, to strengthen the agricultural sector focused on modernizing the sector to ensure increased productivity that would pave the way for competitiveness. These initiatives focused on crop modifications and improvements with such crops as cassava, cocoa and rice among others receiving utmost attention (Diao et al, 2012).

\section{The Nature of National Security Challenges in Nigeria}

Nigeria is not at war in the real sense of the word but the carnage resulting from various forms of insecurity qualifies it to be regarded as conflict-ridden and at war. Conventionally, the threshold required to classify an armed conflict as a civil war is to record 1,000 battle deaths (Dupuy \& Rustad, 2018; Guseh \& Oritsejafor, 2019). Nigeria has consistently recorded deaths in excess of 1,000 from various conflicts unleashed by various groups across the country for decades. Both the Nigeria Security Tracker and the Armed Conflict Location and Event Data Project (ACLED) estimated the total number of deaths associated with the Boko Haram Terrorist group alone between June 2011 and June 2018 at 34,261 and 37,530 people (Campbell \& Harwood, 2018). Apart from the Boko Haram sect, there are other sources of violent deaths, which include intracommunity conflicts, herders-farmers' conflicts, clashes between security agencies and socio- 
cultural and religious groups and other criminal activities, especially ransom kidnappings. In 2018 alone, there were about 10,665 fatalities from various types of violence in Nigeria with the highest source of violent deaths resulting from criminal activities, which recorded 3,425 deaths in 1,191 incidents (Ukoji et al, 2019).

In addition to the deadly activities of the Boko Haram sect in the northeastern geopolitical zone of the country, another major threat to national security with serious implications for food security is the menace of Fulani herdsmen. The Fulani herders are mainly nomadic as they traverse the entire country in search of pastures for their herds. The transhumance tradition of the Fulani herders has often pitted them against sedentary farmers as a result of the destruction of the farms of the latter. In the past, precisely before 1999, these conflicts were well managed by the herders and farmers that they never escalated to the level of recording fatalities. However, since 1999, when Nigeria returned to democratic rule, conflicts between the Fulani herders and farmers gradually assumed a different tone, frequency, ubiquity, complexity and lethality with the traditional dispute mechanisms becoming inadequate to contain them. The lethality of violence unleashed by the Fulani herders led the Institute for Economics and Peace to capture them in the global terrorism index and classify them as a terrorist group as well as name them as the fourth deadliest group in 2014 after having been responsible for the death of 1,229 people (IEP, 2015). This classification was instructive considering that in the previous year, i.e., 2013, the group was responsible for only 63 deaths (Burton, 2016).

Since 2014, the Fulani herders are still deadly as they are responsible for various forms of attacks, especially ransom kidnappings and militia expeditions against farming communities considered antagonistic to their herding and pasturing activities. What must have emboldened the spates of attacks by the Fulani herders is the nonchalance of the Nigerian government despite the international classification of these herders as terrorists. The source of the boldness of the Fulani herders is linked to the open support of their socio-cultural organizations, notably the Miyetti Allah Kautal Hore, Miyetti Allah Cattle Breeders Association of Nigeria and Fulani Nationality Movement as well as the tacit support of the Nigerian president, Muhammadu Buhari. Despite the perception of Nigerians that the presidency is shielding the herder-killers and their sponsors, the government has not done anything substantial to controvert this perception (International Crisis Group, 2017; Amnesty International, 2018; llo et al, 2019).

The boldness of the Fulani herders could be seen in the type of sophisticated weapons at their disposal. In the past, they only carried and relied on long wooden staff, machetes, and bows and arrows. But now, they parade the Soviet assault rifle, Avtomat Kalashnikova (AK47). And, with these weapons, they have been unleashing terror on farming communities across Nigeria. For instance, between 2010 and 2013, the Fulani herders were responsible for killing only 80 people compared to 1,229 people they killed in 2014 alone. Recent estimates paint a very distressing picture of carnage. It is estimated that more than 10,000 persons lost their lives in the past decade from the violence unleashed by Fulani herders on farming communities. Out of this figure, more than 6,000 persons were casualties in the past two years (Kwaja \& Ademola-Adelehin, 2018; Ilo et al, 2019). A further breakdown showed that fatalities resulting from conflicts between Fulani herders and farmers in 2016 alone was about 2,500 persons. Similar high trend in fatalities manifested between 2011 and 2016 when more than 2,000 deaths on average were recorded (International Crisis Group, 2017). Updated data from the Nigeria Security Tracker documented that fatalities from Fulani herders-farmers' conflicts in 2017 and 2018 were 1,041 and 2,037 deaths respectively (Campbell, 2018). As the Fulani herders were unleashing violence across the country, so was the Boko Haram sect terrorizing the northeastern geopolitical zone. The record of fatalities linked to Boko Haram conflicts in 2018 showed a death toll of 2,016 persons (Campbell, 2018; Ilo et al, 2019). The combined effect of these conflicts is the disruption of activities necessary for food production with serious implications for food security.

The various conflicts have also created internal displacement. Since 2013, the activities of the Boko Haram group have been responsible for the displacement of 2.4 million people and putting more than seven million people at the risk of starvation (Campbell \& Harwood, 2018; UNHCR, 2018). Across the major states in Nigeria where the Fulani herders have unleashed terror, a necessary fallout is internal displacement arising from the destruction of the ancestral homes of the 
victims. For instance, estimates put the number of people displaced in Nigeria's Middle Belt states of Benue, Kaduna, Nasarawa and Plateau states at over 620,000 persons (Kwaja \& AdemolaAdelehin, 2018). The impact of displacement on these farming communities is that their contributions to food production in the country are lost as they are not in any position to continue with their occupation of farming. The implication is the deepening of the food insecurity challenge in the country.

\section{Hanging in the Balance: National Insecurity as Antithesis to Food Security}

Nigeria is the most populous country in black Africa. Its population has always been on the increase since it achieved statehood. Prior to 2013, the country's population growth rate was 2.8 percent but since then, the growth rate has been 3.1 percent (CBN, 2018). The implication is that the country's population as at 2018 was 198.1 million with projections for persistent growth due to high fertility rate and improved child and maternal mortality (NBS, 2018; CBN, 2018). What this means is that Nigeria has an ever-expanding need for food in order to meet the food and nutrition needs of its population and achieve food security. The current situation is that Nigeria lacks both the capacity and capability to produce enough food to feed its population despite its favorable agro-ecological conditions. In other words, Nigeria is food insecure. According to FMARD (2016, p. 8), "Nigeria still imports about [US] $\$ 3$ to $\$ 5$ billion worth of food annually, especially wheat, rice, fish and sundry items, including fresh fruits". The burgeoning population means that more and more resources would be devoted to food importation in order to meet the basic food needs of the country.

Therefore, Nigeria's quest to rediscover and reposition agriculture in line with ECOWAP/CAADP agenda is two-pronged, namely, to modernize agriculture for enhanced productivity as well as competitiveness, and to develop strategic agricultural value chain approach for crops, livestock (including poultry) and fisheries. Both of these preoccupations are essentially aimed at addressing the food insecurity faced by the country. Nigeria has mobilized enormous investments in the agricultural sector in order to beef up food production and thus bridge demandsupply gaps in various staple foods. These investments have tended to focus on addressing the productivity challenge and the attendant hiatus between domestic production and demand. The productivity challenge is a product of inefficiency arising from continued application of outdated input system and farming models. While making efforts to modernize the agricultural sector, emphasis has also been placed on developing quality crops by revolutionizing seed varieties, fertilizer distribution system, irrigation system and general agronomy practices.

It is generally recognized that the translation of this noble intention of revitalizing the agricultural sector into concrete reality could only be possible when various agencies of government collaborate to provide infrastructure necessary to create a conducive agricultural environment. At the apex of the checklist of actions necessary to create a conductive environment in which agriculture could thrive is "improved security of farming communities to reduce [the] incidence of criminality" (FMARD, 2016, p. 5). Table 1 below shows that Nigeria is food insecure as there is a wide gap between domestic demand and supply. What this implies is that there is substantial foreign exchange flight out of the country through importation to augment the shortfalls. The overall implication is that farmers lose income that would otherwise have accrued to them and the agricultural sector continues to stagnate thereby losing its potential to generate employment.

Table 1: Gaps in demand and supply of selected staple crops (2016 Estimate)

\begin{tabular}{l|c|l}
\hline Crop & Demand (tons) & Supply (tons) \\
\hline Rice & 6.3 million & 2.3 million \\
Wheat & 4.7 million & 0.06 million \\
Maize/Corn & 7.5 million & 7.0 million \\
Soya Beans & 0.75 million & 0.6 million \\
Tomato & 2.2 million & 0.8 million \\
\hline
\end{tabular}

Source: FMARD, 2016 
The insecurity in Nigeria is having a serious negative impact on farming communities as it prevents them from engaging in crop production at optimal levels. Between 2011 and 2015, reasonable progress was made in the resuscitation efforts of the government. For instance, through the initiative known as the Growth Enhancement Scheme (GES), a database of smallholder farmers was created, which facilitated the efficient distribution of farm inputs, especially fertilizer and improved higher yielding crop varieties to these farmers. Similarly, success was recorded in the concession of federal warehouses and storage assets (FMARD, 2016). All of these efforts were aimed at closing the huge demand-supply gap in crop production.

In recent times, insecurity has negatively impacted agricultural production. Agricultural activities in the northeast of Nigeria is completely suspended as a result of the terrorist activities of the Boko Haram group in that geopolitical zone. The devastation, which the activities of Boko Haram has caused, is not only obvious but also far-reaching in its impact on agriculture. Besides the Boko Haram group, insecurity in Nigeria has been aggravated by the criminal activities of sundry groups. The group with the most devastating impact is the Fulani herders whose murderous campaigns have targeted farming communities, with no challenge from the state (Amnesty International, 2018; Ilo et al, 2019). Since 2013, there has been a steady increase in the number of displaced persons as a result of conflicts across Nigeria. United Nations sources estimated that over 2.4 million people have so far been displaced with new records of displacement from conflicts expanding the number (UNHCR, 2018). According to IDMC (2019), between January and June 2019, about 142,000 new displacements were recorded with a caveat that the figure could most likely be an underestimate. Out of this figure, 140,000 people were displaced through conflict and 2,000 people were displaced because of disasters.

The displacement of farming communities as a result of attacks by armed groups, criminal violence and banditry is associated with an alarming rise in food and nutrition insecurity due to nonavailability of food. The UNHCR's Deputy High Commissioner underscored the gravity of conflictinduced food insecurity when he was quoted to have said, "the future of young generations in the region is at stake, as food insecurity not only affects the dignity of families, but has serious consequences on the physical and cognitive development of children" (UNHCR, 2018). The overall implication is reinforcing cyclic interconnections that would create and sustain intractable security crisis. The intractability of insecurity would result from the clash of national insecurity and food insecurity. In other words, with national insecurity making it impossible for farmers to engage in their farm activities, food shortages would result. As food shortages result, it would create disaffection, which in turn spawns a new round of insecurity due to the intensification of food crisis and mass reaction to it. Thus, there would be constant insecurity caused by the interplay of national insecurity and food insecurity. Of course, this scenario could be averted through massive importation of food to bridge the gap. But it would have implications for national development due to capital flight and the deepening of poverty.

\section{Conclusion}

Although there is an ongoing effort by the government through the instrumentality of the APP to reposition the agricultural sector and make it the engine of Nigeria's economic growth, however, the effort can only yield expected dividends if the government does the needful with regards to national insecurity. There is no way the country can promote productivity or achieve competitiveness where symbolically, physically, and psychologically people feel unsafe. The direct implication of national insecurity on food production was captured by llo et al (2019), when they recognized that it undermines farming capacity and spawns the likelihood of galloping food prices, all of which exacerbate poverty and hunger and signpost a likely nationwide food crisis.

National insecurity has caused serious disruptions in Nigeria's agricultural activities. While millions of farmers have been uprooted and displaced from their ancestral farming communities, others are perpetually afraid for their lives and as such cannot optimally engage in farming activities. The direct implication is declining productivity with attendant shortfalls, both of which further deepen the contradictions surrounding agricultural production in Nigeria and the prospects of food security. What the Nigerian government must do to be track with its plans to reposition the 
agricultural sector is to urgently deal with the insecurity that characterizes the farming communities. There is a far-reaching implication on Nigeria's security architecture if food insecurity is not reversed and resolved. Under different scenarios, food insecurity can create national insecurity or be a consequence of national insecurity. In other words, national insecurity can deepen food insecurity as we are witnessing with the disruptive activities of the Boko Haram and Fulani herdsmen. On the other hand, food insecurity can trigger agitations, which could create security crisis that undermines national security. This vicious cycle may go on and on and produce complex security situations that could ultimately weaken and undermine the state.

\section{Acknowledgement}

The Authors acknowledge the publication grant from the Landmark University Centre for Research, Innovation and Development (LUCRID) for this paper.

\section{References}

Amnesty International. (2018). Harvest of death: three years of bloody clashes between farmers and herders in Nigeria. Abuja: Amnesty International Ltd. Retrieved from https://reliefweb.int/sites/reliefweb.int/files /resources/AFR4495032018ENGLISH.PDF

Berazneva, J. \& Lee, D. R. (2013). Explaining the African Food Riots of 2007-2008: An Empirical Analysis. Food Policy, 39: 28-39. doi:10.1016/j.foodpol.2012.12.007.

Burton, G. (2016). Background report: The Fulani herdsmen. Retrieved from https://medium.com/@gfburton /background-report-the-fulani-herdsmen-part-i-key-findings-introduction-and-history-383c10f8137c

Campbell, J. (2018, December 20). The numbers behind sectarian violence in Nigeria. Council on Foreign Relations. Retrieved from https://www.cfr.org/blog/numbers-behind-sectarian-violence-nigeria\#main-content

Campbell, J. \& Harwood, A. (2018, August 20). Boko Haram's deadly impact. Council on Foreign Affairs. Retrieved from https://www.cfr.org/article/boko-harams-deadly-impact

CBN (Central Bank of Nigeria). (2018). Central Bank of Nigeria annual report, 2018. Abuja: CBN. Retrieved from https://www.cbn.gov.ng/Out/2019/RSD/2018\%20AR\%20KAMA1.pdf

Diao, X., Nwafor, M., Alppuerto, V., Akramov, K. T. Rhoe, V. \& Salau, S. (2012). Nigeria. In Diao, X., Thurlow, J., Benin, S. \& Fan, S. (Eds.), Strategies and priorities for African agriculture: Economywide perspectives from country studies (pp. 211-244). Washington DC: International Food policy Research institute.

Downie, R. (2017). Growing the agriculture sector in Nigeria. A Report of the CSIS Global Food Security Project. Retrieved from https://csis-prod.s3.amazonaws.com/s3fs-public/publication/170317_Downie AgricultureSectorNigeria_Web.pdf

Dupuy, K. \& Rustad, S. A. (2018). Trends in armed conflict, 1946-2017. Retrieved from https://reliefweb.int/sites/reliefweb.int/files/resources/Dupuy\%2C\%20Rustad-\%20Trends\%20in\%20Armed \%20Conflict $\% 2$ C $\% 201946 \%$ E2\%80\%932017\%2C\%20Conflict\%20Trends\%205-2018.pdf

Eigege, J. \& Cooke, J. (2016). Tracing the roots of Nigeria's agricultural decline. Center for Strategic and International Studies (CSIS). Retrieved from https://csis-prod.s3.amazonaws.com/s3fspublic/publication/160505_Eigege_NigeriasAgriculturalDecline_Web.pdf

Fadare, O., Akerele, D., Mavrotas, G. \& Ogunniyi, A. (2019). Effect of conflict and food price shocks on calorie intake and acute malnutrition in Nigeria: A micro-panel data analysis. Paper presented at the 93rd Annual Conference of the Agricultural Economics Society, University of Warwick, England 15 - 17 April 2019. Retrieved from https://EconPapers.repec.org/RePEc:ags:aesc19:289676

FAO (Food and Agriculture Organization of the United Nations). (2003). Trade reforms and food security: Conceptualizing the linkages. Rome: Food and Agriculture Organization of the United Nations. Retrieved from http://www.fao.org/3/a-y4671e.pdf

FAO (2012). Committee on world food security: Coming to terms with terminology. Thirty-ninth session, Rome, Italy, 15-20 October. Retrieved from http://www.fao.org/3/MD776E/MD776E.pdf

FAO, IFAD (International Fund for Agricultural Development), UNICEF (United Nations Children's Fund), WFP (World Food Programme) and WHO (World Health Organization). (2019). The state of food security and nutrition in the world 2019: Safeguarding against economic slowdowns and downturns. Rome: FAO.

FMARD (Federal Ministry of Agriculture and Rural Development). (2010). ECOWAP/CAADP process: National agricultural investment plan (NAIP) 2010-2013. Retrieved from http://www.interreseaux.org/IMG/pdf_NATIONAL_AGRIC__INVEST-_PLAN_FINAL_AUG17.pdf

FMARD (2011). Agricultural transformation agenda: We will grow Nigeria's agricultural sector. Retrieved from http://unaab.edu.ng/wp-content/uploads/2012/10/Agricultural\%20Transformation\%20Blue\%20Print.pdf 
FMARD. (2016). The agriculture promotion policy (2016 - 2020): Building on the successes of the ATA, closing key gaps. Retrieved from https://fscluster.org/sites/default/files/documents/2016-nigeria-agric-sectorpolicy-roadmap june-15-2016_final1.pdf

Guseh, J. S. \& Oritsejafor, E. O. (2019). Governance and democracy in Africa: Regional and continental perspectives. Lanham, Maryland: Lexington Books.

IDMC (Internal Displacement Monitoring Centre). (2019, September 12). Mid-year figures: Internal displacement from January to June 2019. Retrieved from http://www.internal-displacement.org/sites/default/files/inlinefiles/2019-mid-year-figures_for\%20website\%20upload.pdf

IEP (Institute for Economics and Peace). (2015). Global terrorism index 2015: Measuring and understanding the impact of terrorism. Retrieved from https://reliefweb.int/sites/reliefweb.int/files/resources/2015\%20Global \%20Terrorism\%20Index\%20Report_0_0.pdf

Ikpeze, N. I, Soludo, C. C \& Elekwa, N. N. (2004). The political economy of the policy process, policy choice and implementation". In Charles Chukwuma Soludo, Michael Osita Ogbu \& Ha-Joon Chang (Eds.), The politics of trade and industrial policy in Africa: Forced consensus? (pp. 341-367). Ottawa: International Development Research Centre/Trenton, NJ: Africa World Press, Inc.

Ilo, U. J., Jonathan-Chaver, I \& Adamolekun, Y. (2019, January 23). The deadliest conflict you've never heard of: Nigeria's cattle herders and farmers wage a resource war. Foreign Affairs. Retrieved from https://www.foreignaffairs.com/articles/nigeria/2019-01-23/deadliest-conflict-youve-never-heard

International Crisis Group (2017). Herders against farmers: Nigeria's expanding deadly conflict. Africa Report No. 252. Retrieved from https://d2071andvip0wj.cloudfront.net/252-nigerias-spreading-herder-farmerconflict.pdf

Kolavalli, S., Flaherty, K., Al-Hassan, R. \& Baah, K. O. (2010). Do comprehensive Africa agriculture development program (CAADP) processes make a difference to country commitments to develop agriculture? The case of Ghana. IFPRI Discussion Paper 01006 . Retrieved from http://citeseerx.ist.psu.edu/viewdoc/download?doi=10.1.1.226.2918\&rep=rep1\&type=pdf

Kwaja, C. M. A \& Ademola-Adelehin, B. I. (2018) Responses to conflict between farmers and herders in the middle belt of Nigeria: Mapping past efforts and opportunities for violence prevention. Retrieved from https://www.sfcg.org/wp-content/uploads/2018/03/Responses-to-Conflicts-between-Farmers-and-Herdersin-the-Middle-Belt-FINAL.pdf

Lanicci, J. M., Ramsay, J. D. \& Murray, E. H. (2017). Re-conceptualizing environmental security as resilience: Strategic planning for human and national security. Journal of Human Security and Human Resilience, 1(1), 1-32.

Louw, L. and Lubbe, H. J. (2017). Threats to security posed by ISIS in Syria: A human security approach. Journal of Human Security, 13(1), 16-21. DOI: 10.12924/johs2017.13010016.

Navarro, R. L. (2017, May 25). Food security: A requisite to national security. Business Mirror. Retrieved from https://businessmirror.com.ph/2017/05/25/food-security-a-requisite-to-national-security/

NBS (National Bureau of Statistics) (2018). Demographic statistics bulletin 2017. Retrieved from https://nigerianstat.gov.ng/download/775.

NEPAD (New Partnership for Africa's Development) (2003). Comprehensive Africa agriculture development programme (CAADP). Midrand, South Africa: NEPAD. Retrieved from http://www.fao.org/nr/water/aquastat/sirte2008/NEPAD-CAADP\%202003.pdf

Nnoli, O. (2006). National security in Africa: A radical new perspective. Enugu: Snaap Press Ltd.

Notaras, M. (2011, August 31). Food insecurity and the conflict trap. Our World. Retrieved from https://ourworld.unu.edu/en/food-insecurity-and-the-conflict-trap

Nwozor, A. (2013). National security, religious anarchism and the politics of amnesty in Nigeria. Covenant Journal of Politics and International Affairs, 1(1), 1-14.

Nwozor, A. (2018). African Union, state-building and the challenges of state fragility in Africa. Austral: Brazilian Journal of Strategy \& International Relations, 7(13), 64-84. DOI: 10.22456/2238-6912.80373

Okotie, S. (2018). The Nigerian economy before the discovery of crude oil. In Ndimele, P. E. (Ed.), The political ecology of oil and gas activities in the Nigerian aquatic ecosystem, (pp. 71-81). London: Academic Press. DOI: 10.1016/b978-0-12-809399-3.00005-7

Paul, I. A. (2015). A historical perspective of petroleum on Nigeria's economic crisis since independence. Global Journal of Human-Social Science, 15(2), 17-24.

Pinto, B. (1987). Nigeria during and after the oil boom: A policy comparison with Indonesia. The World Bank Economic Review, 1(3), 419-445.

Popoola, N. (2018, December 3). Nigeria cut food imports, saved \$21bn in 34 months - Emefiele. Punch. https://punchng.com/nigeria-cut-food-imports-saved-21bn-in-34-months-emefiele/

Smith, I. (2018). Promoting commercial agriculture in Nigeria through a reform of the legal and institutional frameworks. African Journal of International and Comparative Law, 26(1), 64-83. DOI: 10.3366/ajicl.2018.0220 
Ukoji, V., Ayodokun, A. \& Eze, V. (2019). Nigeria watch: Eighth report on violence in Nigeria. IFRA-Nigeria Working Papers Series, No. 59/15/03/2019. Retrieved from https://www.ifra-nigeria.org/files/55/NigeriaWatch-Project/151/UKOJI,-AYODOKUN,-EZE-(2019)-Nigeria-Watch-Report-on-violence-in-Nigeria.pdf

UNHCR (UN High Commissioner for Refugees). (2018, February 1). UNHCR and partners seek US\$157 million to aid Boko Haram displaced. Retrieved from https://www.unhcr.org/5a7184f34.html 